\title{
Nematode Parasites in a Freshwater Fish Glossogobius giuris(Hamilton-Buchanan, 1822) at Lower Manair Dam, KarimnagarDt. Andhra Pradesh, India.
}

\author{
B. Leela and K. Rama Rao \\ Department of Zoology Government Degree College, Jammikunta, Satavahana University, Karimnagar \\ Dt.Andhra Pradesh, India.
}

\begin{abstract}
The freshwater gobid fish Glossogobius giuris were collected from Lower Manair Dam at every week and all fishes were examined for the presence of internal nematode parasite Rhabdochona garuaiin the visceral organs. On an average prevalence $40.65 \%$ were found infected and 2.30 parasites are present in each individual infected and abundance is 0.92.The results indicate that the parasitic mean intensity3.14 and relative density 1.40 is quite high in January and high prevalence55.88 in October. The prevalence 10.00 and mean intensity 1.50are less in April and Relative density 0.47in June.
\end{abstract}

Key Words: Nematode parasites, Digestive tract, Prevalence, Mean Intensity, Relative Density

\section{Introduction}

Fish helminth parasites are generally found in all freshwater fishes. The parasite prevalence and intensity depend on many factors like parasite and its life cycle, host and its feeding habits and the physical factors of water body where the fish inhabit. The parasitic diseases, either alone or in conjunction with other environmental stresses, may influence weight or reproduction of the host, alter its population characteristics and affect its economic importance (Rohde). Parasites occupy a definite position in the animal kingdom for their remarkable adaptations and damaging activities to host. The importance of parasite is related directly to the fish that may affect the general public health (Hoffman).Fish flesh is nutritionally equivalent to meat (mutton) in protein content, low in saturated fats and high in essential minerals and vitamins. To obtain healthy and quality meat fish, it is necessary that the fish should be free from all types of infections like viral, bacterial and parasitic. The nematode parasites genus Rhabdochona studied by Rehana R, Bilqees FM, (1973) Rhabdochona cavasiussp. n. from a freshwater fish Mystus vitattusof Kalri lake Sindh, Pakistan and a new species of the genus Rhabdochona from the fish Cybium guttatum reported by Arya, S.N and Johnson, S., (1977a).Gupta, S.P and Srivastava, A.B., (1982), Gupta, V\&Bakshi, R., (1979) and Gupta, V and Jaiswal, L.R.K., (1988) were reported new nematode parasites from freshwater fishes of Lucknow. The helminths are found in almost all the animals including fish throughout the world (Bychowsky, (1962). Trematodes live in all vertebrates inhabiting the digestive tract, accessory tubes and cavities (Roberts \&Janovy, 1996) and have been reported from different species of fish (Needham \& Wootten, 1978; Dhar \& Kharoo, 1984; Nazir, 1996). Helminths damage health of fish by inducing variable intensity of infection depending upon the quality of environmental conditions (Read, 1992). Glossogobius giurisis a carnivorous fish commonly found in reservoirs, rivers and estuaries. Its food mainly consists of small fish and larvae of crustaceans. It mostly lives in clear and shallow water accumulated after rain in dams and reservoirs. The present study therefore aims to investigate the prevalence, mean intensity and relative density of parasites Rhabdochona garuai(Ali. 1956)in Glossogobius giuris. The nematode parasite R.garuai taxonomic classification is kingdom: Animalia, Phylum: Nematoda, Class: Secenentea, order: Spirurida, Family: Thelaziidae, Genus: Rhabdochona, Species: garuaiin Glossogobiusgiurisat Lower Manair Dam at Karimnagar Dt., Andhra Pradesh.

\section{Materials And Methods}

Freshwater fish Glossogobius giuris specimens were collected from Lower Manair Dam at Karimnagar district, India. Fish sampling were collected by using gill nets, cast nets and hooks. All the fishes were dissected at live condition at spot for the diagnosis of different sizes of nematode parasites. The stomach and intestine were removed carefully and kept separately in petridish.Fishes were dissected one by one exposing their visceral organs for nematode parasites. All the parasites recovered from the visceral organs were preserved in $70 \%$ alcohol. They were cleaned and kept in small vials for the study of their morphology for identification. The parasite number and place of their attachment were also recorded. External and internal morphological characters of each worm were recorded for further species identification according to Bykovskayaet al. (1964). This identification was confirmed by the description of the same or similar parasites (Zaidi and Khan, 1976; Akram, 1988a, b; Khan and Bilqeese, 1990; Khan, 1991; Habib, 1996; Nazir, 1996). 
Parasite identification: Drawings of the parasites were made with the help of camera lucid. External and internal morphology of the parasites were sketched. Anterior and posterior regions of the parasite were drawn at high magnification in the laboratory.

\section{STATISTICAL ANALYSIS}

Ecological terms are studied as per Margolis.

(A) Prevalence $=$ Total No. of Hosts Infected X 100

Total No. of Hosts Examined

(B) Mean Intensity $=$ Total No. of parasites

Total No. of Infected Hosts Examined

(C) Relative Density $=$ Total No. Parasites

Or Abundance Total No. of Hosts Examined

\section{Results And Discussion}

Present investigation an average per year $40.65 \%$ fishes were found to be infected with nematode parasites Rhabdochonagaruai, the mean intensity is 2.3 and relative density is 0.92 indicated in (Table I).These nematodes were found in the intestine and visceral organs of the fish Glossogobius giurisexcept the month of May (Data is not available). The photographs (Fig: 1,2,3) (16 mega pick cells) of these nematodes shows external morphology of both male and female worms were identified as Rhabdochona garuai following Ali (1956), Zaidi and Khan (1976). Leningrad (1999) pointed out that an increase in temperature to certain limits accelerates the fission and larval development of parasites while beyond that limit these processes slow down. In the present study, the water temperature during summer increases in the reservoir and surface water temperature becomes high $\left(>38^{\circ} \mathrm{C}\right)$ during summer, which was probably not suitable for the development of intermediate stages of nematode parasites. The increase in temperature probably caused the eggs degeneration, destroyed many parasites before becoming adults.

The prevalence of infection of nematode parasites in G. giuris during different months is listed in Table: 1, Fig: 4. the parasites show highest effect in the month of October 55.88\%, lowest in April 10.00. The mean intensity is highest in the month of January 3.14, lowest in April 1.50. The relative density is highest in the month of January 1.40, lowest in June 0.40.Raja Mohammad Rafiqueet al (2003) studied a freshwater fish Mystus vittatus were collected from a pond at Roy walla, Kasur and examined for the presence of intestinal helminths. Only one species of nematode Rhabdochona magna was recovered from intestine of the fish. Out of 48 fish only 18 (37.5\%) were found infected. The mean intensity of nematode infection remained 6.5.Muhammad Shafiq Ahmed et al (2007) studied that all $(100 \%) \mathrm{H}$. fossilis were infected with nematodes, Procamallanus heteropneustus, only $6(37.5 \%) M$. vittatus were found infected with nematodes, Rhabdochona magna. Sengataunsaensisand $5(31.25 \%)$ were infected with nematodes, $R$. magna. The mean intensity of infection was 14.36 in H.fossilis.

Theseasonal variations and efficacy of the nematode parasites in the Lower Manair Dam was lowest prevalence (28.92\%), mean intensity (1.42) and relative density (0.41) for the premonsoon months, the highest prevalence (46.06\%), mean intensity (2.32) and relative density (1.07) for the monsoon months. In the post monsoon period the results were slightly decreasing when compared to premonsoon months Table: 2, Fig: 5. From the data of prevalence and intensity of infection of nematode parasites studied, it is clear that water temperature have no clear cut impact on the occurrence of nematode parasites. Maximum and minimum value of prevalence and intensity of infection were found both in the months of higher and lower temperatures. The seasonal occurrence of helminth parasites in the fish may also be due to the age of fish host and life cycle of the parasites. Ecological factors have been held widely responsible for the occurrence of the adults.

Live YouTube video subscribed on Feb 5, 2014 - Uploaded by Rama Rao Karri, for watch this video http://www.youtube.com/watch?v=altB2JAtM6s.

\section{Acknowledgement}

The authors are grateful to Commissioner of Collegiate Education, Andhra Pradesh, Govt. Degree College, Jammikunta for facilities provided to carry out the work successfully. 
Table:1.Prevalence of infection of nematode parasites observed monthly in Glossogobius giuris visceral organs during the different months in Lower Manair Dam.

\begin{tabular}{|c|c|c|c|c|c|c|}
\hline Months & $\begin{array}{l}\text { Total No. of Hosts } \\
\text { Examined }\end{array}$ & $\begin{array}{l}\text { Total No. of Infected } \\
\text { Hosts Examined }\end{array}$ & $\begin{array}{l}\text { Total No. of } \\
\text { parasites }\end{array}$ & Prevalence & $\begin{array}{l}\text { Mean } \\
\text { Intensity }\end{array}$ & $\begin{array}{l}\text { Relative } \\
\text { Density }\end{array}$ \\
\hline February & 37 & 12 & 26 & 32.43 & 2.17 & 0.70 \\
\hline March & 17 & 06 & 10 & 35.29 & 1.67 & 0.59 \\
\hline April & 20 & 02 & 03 & 10.00 & 1.50 & 0.15 \\
\hline June & 38 & 12 & 18 & 31.58 & 1.50 & 0.47 \\
\hline July & 25 & 10 & 13 & 45.00 & 1.30 & 0.52 \\
\hline August & 52 & 23 & 48 & 44.23 & 2.09 & 0.92 \\
\hline September & 23 & 12 & 32 & 52.17 & 2.67 & 1.39 \\
\hline October & 34 & 19 & 44 & 55.88 & 2.32 & 1.29 \\
\hline November & 56 & 22 & 52 & 39.29 & 2.36 & 0.93 \\
\hline
\end{tabular}

Table: 2.Seasonal variations and efficacy of the nematode parasites in Glossogobius giurisvisceral organs.

\begin{tabular}{|c|c|c|c|c|c|c|}
\hline Seasons & $\begin{array}{l}\text { Total No. of Hosts } \\
\text { Examined }\end{array}$ & $\begin{array}{l}\text { Total No. of } \\
\text { Infected Hosts } \\
\text { Examined }\end{array}$ & $\begin{array}{l}\text { Total No. of } \\
\text { parasites }\end{array}$ & Prevalence & $\begin{array}{l}\text { Mean } \\
\text { Intensity }\end{array}$ \\
Density
\end{tabular}

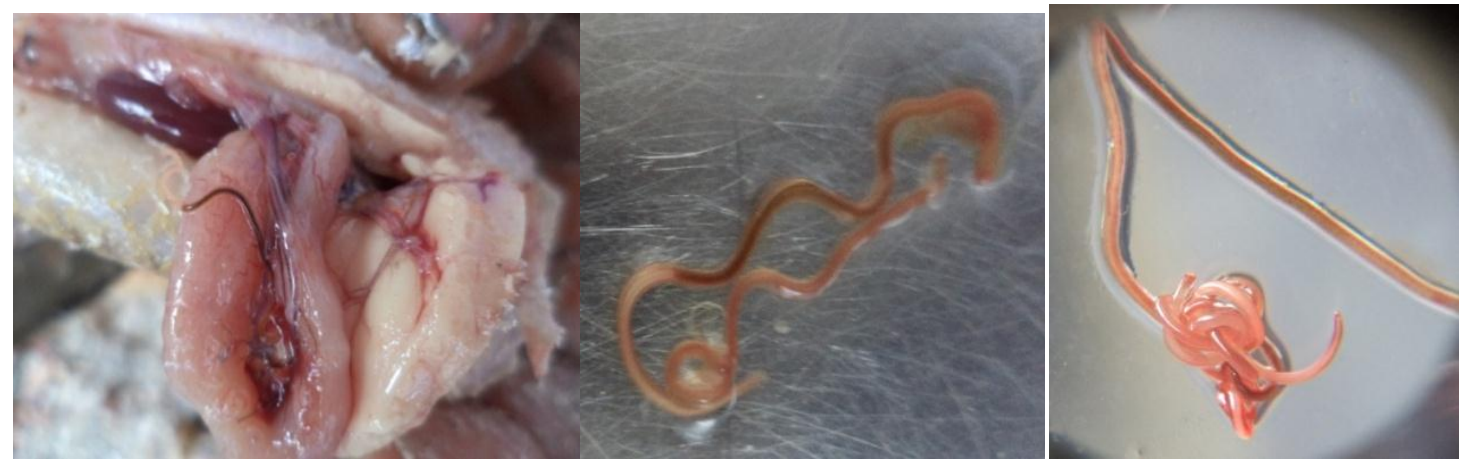

Fig:1. R. giuris in Glassogobius visceral organs Fig: 2. Male and and Female parasites. Fig: 3. Male and Female G. giuris

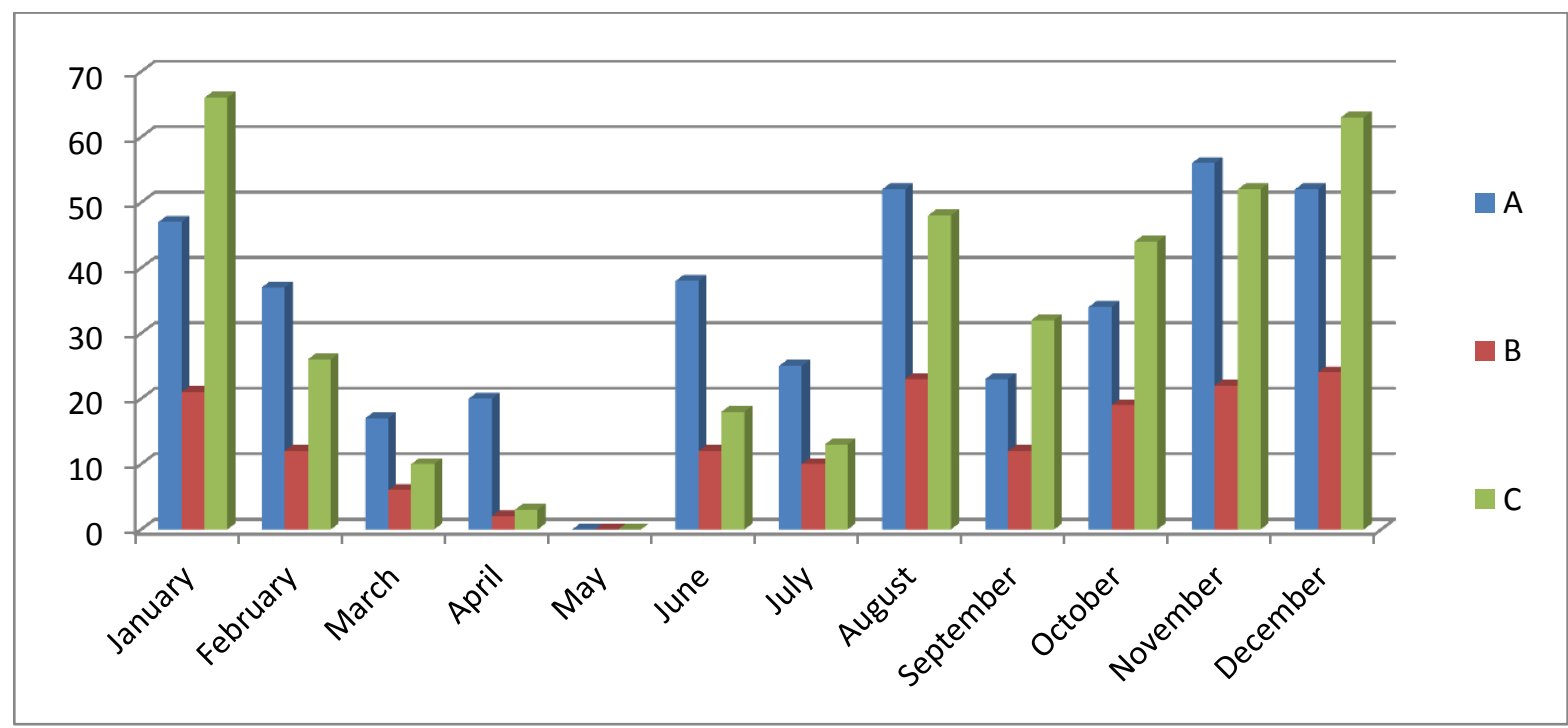

Fig: 4. Prevalence of infection of nematode parasites observed monthly in Glossogobius giuris. A. Total No. of Hosts Examined. B. Total No. of Infected Hosts Examined. C. Total No. of parasites. 


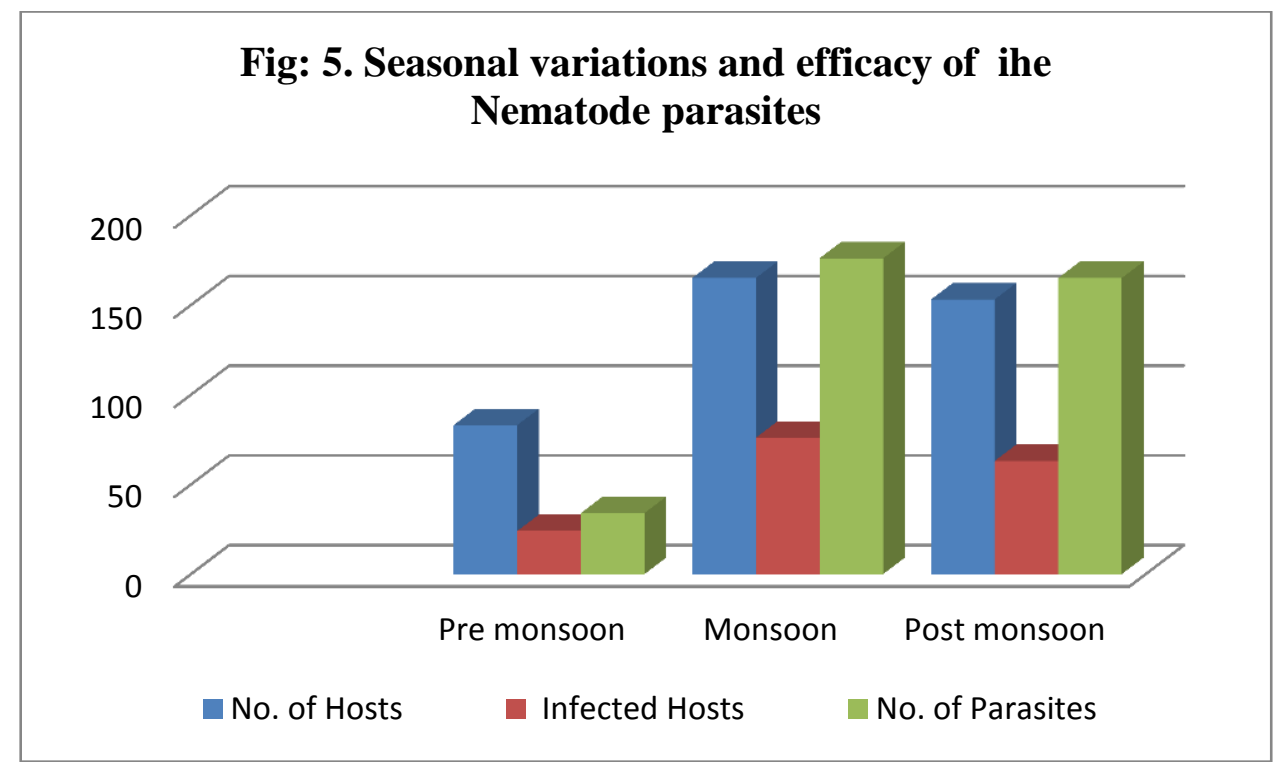

\section{References}

[1]. Agarwal, V., 1965 b. Some new nematode parasites from fresh water fishes of Lucknow. Indian Journal of Helminthology ., 17(1) : $1-17$.

[2]. AKRAM, M., 1988a. On the subfamily procamallaninae (Yeh, 1960). Part-I. Systematic studies on the genus Procamallanus (Baylis, 1923) with note on the genus Platocamallaniis Bilqees and Akram, 1982 (Nematoda: Camallanidae). Rec. Zoot. Sur., 11:70-85.

[3]. Arya, S.N and Johnson, S., 1977a. A new species of the genus Rhabdochona (Nematoda: Rhabdochonidae) from the fish Cybiumguttatum. Journal of Zoological Research. 1(1) : 22-25.

[4]. Bychowsky, B.E., 1962. MonogenticTrematodes: Their Systametic and Phylogeny, p. 242. Graphic Arts Press.

[5]. Bykovskaya, I.E., pavlovskaya, A.V., gusev, M. N., dubinina, N.A., dubinina, N.A., izyumova., T.S., smirnova, I.L., sokolov-skaya, G.A., shtein, S.S. and shul'man, V.M., 1964. Key to parasites of freshwater fish of the U.S.S.R. Israel Program for Scientific Translations, Jerusalem.

[6]. Dhar, R.L. and V.K. Kharoo, 1984. On a new trematode Alloceradiumfotedarisp. Of the family Allocredidae from the intestine of Schizothiraxnigar, a freshwater fish of Kashmir, India. Indian J. Helminthol., 36: 32-5.

[7]. Gupta, S.P and Srivastava, A.B., 1982. Nematode parasites of fishes: On four new species of the genus RhabdochonaRailliet, 1916 from fresh water fishes of India. Rivista di parassitologia., 43(2): 265-274.

[8]. Gupta, V and Bakshi, R., 1979. Nematode parasites of fishes. I. Three new nematode parasites from freshwater fishes of Lucknow. Indian Journal of Helminthology., XXXI(2):157-168.

[9]. Gupta, V and Jaiswal, L.R.K., 1988. Three new nematode parasites from freshwater fishes of Lucknow. Indian Journal of Helminthology., 40(1): 64-77.

[10]. Habib, S.1996. Studies on the helminth parasites of a freshwater fish, Wallagoattu. M.Sc. thesis, Department of Zoology, Govt. College, Lahore, P. 35

[11]. Knan, A., 1991. Studies on some helminth parasites of freshwater fishes of Sind. Ph.D. thesis, Department of Zoology, University of Karachi, pp.376.

[12]. Leningrad, E., 1999. Parasites of freshwater fish and the biological control, pp: 137-77. Israel Program for Scientific Translation Ltd. S. Monson Israel.

[13]. Mohammad Rafique, ShahidMahboob, M. Gulzarin, RobinaYaqub and Mushtaq Ahmad. 2002. Helminth Parasites of a Freshwater Fish Mystusvittatu. International journal of agriculture \& biology. 1560-8530/2002/04-1-56-57.

[14]. Nazir, T., 1996. Studies on the helminth parasites of a freshwater fish, Channapunctatus. M.Sc. Thesis Deptt. Zoology, Govt. College, Lahore.

[15]. Needham, T. and R. Wootten, 1978. The Parasitology of Teleosts. In: Ronalad, J.R. and B. Tindall (eds.), Fish Pathology, pp: 151201. London.

[16]. Raja Muhammad Shafiq Ahmed, TahirIqbal, AmjadMahmood, Muhammad Gulzarinand MuhammadAbid. 2007. Helminth parasites of some freshwater fishes. Punjab Univ. J. Zool., Vol. 22 (1-2), pp. 01-06, 2007

[17]. Read, C.P., 1992. Animal Parasitism, p. 265. Inc., Englwood Cliffs, New Jersey.

[18]. Rehana R, Bilqees FM, 1973. Rhabdochonacavasiussp. n.(Nematoda : Rhabdochonidae) from a freshwater fish Mystus vitattus(Ham.) of Kalri lake Sindh, Pakistan. J SciInt Res, 16: 110-111.

[19]. Roberts, L.S. and J. Janovy, 1996. Foundation of Parasitology, 5th ed., p. 482. WMC, Brown, London.

[20]. Zaidi, D.A. and D. Khan, 1976. Cestodes of fishes from Pakistan. Biologia, 157-79. 